\title{
The emergent past: past natural and human disturbances of trees can reduce their present resistance to drought stress
}

\author{
Hans Pretzsch ${ }^{1}$ (D)
}

Received: 25 July 2021 / Revised: 21 September 2021 / Accepted: 24 September 2021 / Published online: 17 November 2021

(c) The Author(s) 2021

\begin{abstract}
Forest tree growth is primarily explained, modelled, and predicted depending on current age or size, environmental conditions, and competitive status in the stand. The accumulated size is commonly used as a proxy for a tree's past development. However, recent studies suggest that antecedent conditions may impact present growth by epigenetic, transcriptional, proteomic, or metabolic changes alongside physiological and structural properties. Here, I analysed the ecological memory effect embedded in the xylem as a tree-ring structure. I used 35 mature Norway spruces (Picea abies (L.) H. KARST.) and 36 European beeches (Fagus sylvatica L.) of the Kranzberg Forest water retention experiment KROOF in South Germany to scrutinise how their past development determines the growth of control plots and plots with 5-year water retention. I hypothesised that the current size and growing conditions determine tree growth and drought stress resistance. Metrics quantifying the trees' recent and past growth, and correlation and linear mixed models with random effects revealed the following ecological memory effects. (1) For both species, the progressive growth course, low inter-annual growth variation in the long term, and low growth deflections in the recent past increased the growth resistance to drought. (2) The correlation between the past growth metrics and current stress reactions revealed that legacy effects could reach back 5-30 years; I found shortand long-term ecological memory. (3) Parameters of model prediction of the basic model with only size as a predictor of tree growth could be improved. The results suggest differences in the internal stem structure and ring pattern cause-specific differences in the trees' functioning and growth. I conclude that a long-term progressive increase and low variation in ring width may improve water conduction and reduce embolism in both species. Annual growth variation and low growth events in the recent past may have primed the morphology and allocation of the Norway spruce to better resist drought. The strong reduction in current growth, drought resistance by irregular growth, and past growth disturbances reveal a memory effect embedded in the tree ring pattern, suggesting further exploration and consideration in tree monitoring, growth modelling, and silvicultural prescriptions.
\end{abstract}

Keywords Antecedent growth $\cdot$ Ecological memory effect $\cdot$ Half-size time $\cdot$ Inter-annual growth variation $\cdot$ Low-growth years $\cdot$ Structural-functional relationships $\cdot$ Tree ring pattern

\section{Introduction}

Classical concepts of understanding, modelling, and silvicultural steering of tree growth posit that individual tree growth depends mainly on the trees current size, age, environmental

Communicated by Peter Biber.

Hans Pretzsch

Hans.Pretzsch@tum.de

1 Chair for Forest Growth and Yield Science, TUM School of Life Sciences, Technical University of Munich, Hans-Carl-von-Carlowitz-Platz 2, 85354 Freising, Germany conditions, and competitive status (von Bertalanffy 1951; Coomes and Allen 2007; Weiskittel et al. 2011; Burkhart and Tomé 2012). Here, the cumulated stem size, crown size, and tree age are commonly used as proxies for a tree's past development and its history's ecological memory. However, research into the growth response to environmental stress provides increasing evidence that current growth can be determined by conditions in the recent past (Walter et al. 2011; Camarero et al. 2018; Bose et al. 2020). Ogle et al. (2015), Johnstone et al. (2016), and Pretzsch (2021a, b) proposed concepts to explore the impacts of the distant past.

Interest in the relationship between past conditions and future growth originates from the desire to mitigate drought 
and other climate change-related stress through silvicultural treatment (Camarero et al. 2018; Ogle et al. 2015). For instance, initial wide spacing or repeated strong thinning results in large xylem vessels that enhance water conduction and growth under normal conditions but may increase the risk of embolism under drought. Hence, low stand densities may improve the drought resistance (Aldea et al. 2017; Martín-Benito et al. 2008; Sohn et al. 2016). Conversely, other studies have found opposite effects (D'Amato et al. 2013; Steckel et al. 2020), where density reduction had positive effects in the short term, followed by negative effects in the long term (D'Amato et al. 2013; Calama et al. 2019). These discrepancies may be resolved when analysing the past treering structure and could help re-evaluate and improve stand density regulation as recommended by Sohn et al. (2016).

Past conditions may affect present growth via epigenetic (Rico et al. 2014; Bose et al. 2020), transcriptional, proteomic, and metabolic (Fleta-Soriano and Munné-Bosch 2016) changes, and also through physiological adjustments (Peltier and Ogle 2019) and changes in the plant structure (Netzer et al. 2019). Trees in seasonal forests have a particular characteristic: their tree ring and crown structurally store their past growth rhythm and can therefore be harnessed to quantify their past using appropriate metrics (Pretzsch, accepted). Thus, tree-ring, crown, and root morphology patterns represent a structural memory embedded in the stem, crown, and root (Backhaus et al. 2014; Ogle et al. 2015). They may affect the trees' functioning and growth, e.g. via light interception, hydraulic conduction, or water and nutrient uptake. Variations in this structure may cause specific differences in functioning and growth curve patterns. Thus, these structural traits may be crucial for analysing the statistical relationship between the past and present and to develop hypotheses regarding the underlying mechanism.

The structural memory embedded in the crown structure may make it challenging to predict tree growth. For instance, the crown length is easy to measure and is often used as a covariate when modelling growth responses (Webster and Lorimer 2003; Pretzsch 2009). Conversely, structural memory embedded within the trunk has been largely neglected (Ogle et al. 2015; Pretzsch under review). For instance, past variation in inter-annual growth, whether a tree's growth was progressive or degressive, and whether a tree suffered lowgrowth years in the past may be relevant for future growth (Camarero et al. 2018). Thus, past development may affect present growth and stress responses (Pretzsch, in revision).

To identify the effects of the past development of trees on their future behaviour, I examined sample trees from the Kranzberg Forest (KROOF) water retention experiment (Pretzsch et al. 1998a, b; 2020, 2014a, b; Goisser et al. 2016; Grams et al. 2021). I used existing information regarding past trajectories, size, competition before the beginning of the stress period, and the stress reaction regarding the annual growth rates in Norway spruces (Picea abies (L.) H. KARST.) and European beeches (Fagus sylvatica L.) in control and five-year water retention plots.

Our objective was to investigate how past human and natural disturbances in trees modify current drought stress resistance. I developed a metric for characterising the stem diameter growth trajectories in the past and analysed how these affect current growth under stress. I aimed to answer the following questions:

Q1: How do current growth responses to drought correlate with metrics characterising the trees' past growth trajectories? Which metrics describing past growth codetermine current growth? How far do ecological memory effects return to a tree's development?

Q2: How do metrics describing past growth trajectories correlate with each other? Which metrics have similar/ differing effects on current tree growth? How do Norway spruce and European beech differ regarding the ecological memory effect?

Q3: Can model predictions of current growth be improved by including metrics characterising individual past development? How does the inclusion of such information regarding the past modify parameters of model prediction, such as the Akaike information criterion (AIC), root mean squared error (RMSE), and the coefficient of determination $\left(\mathrm{R}^{2}\right)$ ?

I hypothesised that tree growth in the recent or more distant past determines the current growth and drought stress resistance of trees, alongside their current size and growing conditions.

I discuss why any ecological memory in trees should be considered when monitoring trees, analysing their growth trend, modelling tree and stand dynamics, and managing trees, especially under climate change.

\section{Materials and methods}

To analyse how past tree development and accumulated structure can modify growth responses to drought stress, I selected mature Norway spruces and European beeches from the well-documented water retention experiment KROOF in Germany (Grams et al. 2021; Pretzsch et al. 2020, 2014a, b). I used the trees with the following data for detailed analyses: their annual tree ring growth from their juvenile state, their growth reactions with and without experimental drought at present, and measurements of their present size, structure, and competitive status in the stand. I thus analysed how much information regarding past development can explain their current growth and usual variables such as present age, stem and crown size, and the trees' competitive status and 
treatment. The site conditions (Göttlein et al. 2012), experimental setup (Pretzsch et al. 2014a, b), effect of extended drought on tree physiology (Goisser et al. 2016; Schäfer et al. 2019; Grams et al. 2021), tree and stand growth (Rötzer et al. 2017a, b; Pretzsch et al. 2020), and soil and mycorrhiza (Nickel et al. 2018) were previously published. Thus, I subsequently report only essential information regarding the KROOF experimental plots and trees used for this study.

\section{Description of study site KROOF water retention experiment}

\section{Study site}

The study site KROOF (longitude: $11^{\circ} 39^{\prime} 42^{\prime \prime} \mathrm{E}$, latitude: $48^{\circ} 25^{\prime} 12^{\prime \prime} \mathrm{N}$, altitude $490 \mathrm{~m}$ a.s.l) is in Southern Germany, approximately $35 \mathrm{~km}$ north-east of Munich. It has an average annual precipitation of $750-800 \mathrm{~mm}_{\text {year }}{ }^{-1}$ and 460-500 $\mathrm{mm}$ during the growing season (May-September). The average annual air temperature is $7.8^{\circ} \mathrm{C}$ and $13.8^{\circ} \mathrm{C}$ on a seasonal basis. The monospecific and mixed species stands of Norway spruce and European beech grow in luvisol originating from loess over Tertiary sediments and provide high nutrient and water supplies (Pretzsch et al. 1998a, b; Göttlein et al. 2012). Depending on soil depth, the water holding capacity for plant-available water ranged between 17 and $28 \%$, while soil $\mathrm{pH}_{\mathrm{H} 2 \mathrm{O}}$ varied between 4.1 and 5.1.

To characterise the water supply for each year, I calculated the index of de Martonne (1926) (M=precipitation/(temperature +10$)$ ) based on the precipitation $(\mathrm{mm})$ and temperature $\left({ }^{\circ} \mathrm{C}\right)$ for the whole year $\left(\mathrm{M}_{\mathrm{y}}\right)$ and for the growing season from April to September $\left(\mathrm{M}_{\mathrm{gs}}\right)$. This index has been widely used in recent studies to describe drought conditions or aridity for a given region (Rötzer et al. 2012; Pretzsch et al. 2013a, b; Quan et al. 2013). The water supply for plant growth improves with increasing $\mathrm{M}$ index. On average, $\mathrm{M}_{\mathrm{gs}}$ was 19.8 and $\mathrm{M}_{\mathrm{y}}$ was 44.6 in 1998-2018.

\section{Rainfall exclusion and control plots}

KROOF has established 12 experimental plots, namely six rainfall exclusion plots and six control plots (Pretzsch et al. 2014a, b; Grams et al. 2021). The plot sizes vary between 110 and $200 \mathrm{~m}^{2}$. Overall, the total area was $868 \mathrm{~m}^{2}$ and $862 \mathrm{~m}^{2}$ for the control and drought treatment plots, respectively. Before rainfall began, exclusion trenching was performed in the spring of 2010 . The soil was trenched to approximately $1 \mathrm{~m}$ deep and $15 \mathrm{~cm}$ wide, lined with a heavyduty plastic tarp impermeable to water and root growth and refilled with the original soil material. At approximately $1 \mathrm{~m}$ depth, a dense clay layer of tertiary sediments prevented further downward-rooting (Häberle et al. 2015; Pretzsch et al. 2016).
At six plots, roofs were installed at approximately $3 \mathrm{~m}$ height underneath the stand canopy to induce rainfall exclusion. In 2014, the throughfall exclusion experiment at KROOF with novel, rain-controlled roof closure began. Triggered by rainfall, the roofs closed automatically and only stayed closed during rain events to exclude unwanted micro-meteorological and physiological effects (Pretzsch et al. 2014a, b). To avoid snow breakage and damage through icing, the roofs were kept open during the winter months. This resulted in small annual precipitation quantities for the rainfall exclusion plots from 2014 to 2018 . The winter precipitation quantities for the five years of the experimental drought were clearly below $150 \mathrm{~mm}$.

From establishing the experiment in 1998 to the present, represents a wide range of different water availabilities. The years 2001-2002 and 2005-2013 were relatively moist, while 2003 and 2015 were extremely dry. Accordingly, the Martonne index varied from 30 to 65 for the whole year and from 15 to 25 for the growing season. The meteorological data originated from the nearby forest weather station Freising, part of the Bavarian Environmental Monitoring System (LWF, 2017). For further information regarding the KROOF, see Göttlein et al. (2012), Häberle et al. (2012), and Pretzsch et al. (1998a, b).

\section{Description of stand and tree characteristics}

\section{Dendrometric survey}

Stand inventory began in 1994 with an inventory of stem coordinates and eight crown radii of all trees alongside stem diameter, tree height, height to crown base, and survival status. The repeated measurements in 1994, 1999, 2005, 2013, and 2018 covered diameter at breast height $(d, \mathrm{~cm})$, tree height $(h, \mathrm{~m})$, height to crown base $(h c b, \mathrm{~m})$, tree survival status at several surveys, and the crown radius projection of the trees in the eight cardinal directions (N, NE, E, SE, S, SW, W, NW) according to standards described by Pretzsch (2009, pp. 115-118). Eight radii were used to calculate the crown projection area in $\mathrm{m}^{2} \quad c p a=\overline{c r}^{2} \times \pi$ using $\overline{c r}=\sqrt{\left(r_{1}^{2}+r_{2}^{2}+\ldots+r_{8}^{2}\right) / 8}$.

For retrospective analysis of annual diameter growth and wood density (Pretzsch et al. 2020), I sampled two increment cores from 69 dominant Norway spruces and European beeches, with approximately half of them on control plots and the other half on the treatment plots of KROOF. The cores were taken at breast height on each sample tree's stem in the $\mathrm{N}$ and $\mathrm{E}$ directions to obtain medium representative increment records. The main wind direction from SW boring from $\mathrm{N}$ and $\mathrm{E}$ was $45^{\circ}$ to this maximum diameter and yielded more representative tree ring widths. To trace back the tree growth as far as possible, cores were taken as 
preferably back to the pith to ensure a boring radial direction. The increment cores were taken with the borer MORA CORETAX (Haglöf, Järfälla, Sweden).

The increment cores were glued on wooden slides, ground, polished on a sanding machine using 120 grit paper, cleaned with compressed air, and analysed to the nearest 1/100 mm using a digital positioning table Digitalpositiometer (Kutschenreiter \& Johann; Britz \& Hatzl GmbH, Gerasdorf, Austria). For cross-dating and synchronisation, the extremely narrow rings in 1976 and 2003 were the most helpful. The radial increments (ir) of the two cores of a tree $\left(i r_{1}, i r_{2}\right)$ were added to obtain a representative time series of the aboveground diameter increment (id) for each tree $\left(i d=i r_{1}+i r_{2}\right)$ for further evaluation.

\section{Stand characteristics}

In the last full survey of the experimental plots in the KROOF in 2018, Norway spruce was 67 and European beech was 87 years old. The experiment comprised plots with monocultures and mixtures of both tree species. Mean and dominant tree sizes were similar in the mono-specific and mixed-species plots. The dominant heights of $34.3 \mathrm{~m}$ for spruce and $33.0 \mathrm{~m}$ for beech indicated optimum growing conditions, namely site indexes of $\mathrm{O} 40$ according to the yield table of Assmann and Franz (1965) for the Norway spruce and I. site class according to Schober (1975) for the European beech. The quadratic mean stem diameters at breast height on the plots were $27.1-36.4 \mathrm{~cm}$, the mean heights were $27.2-36.4 \mathrm{~m}$, and the dominant diameters (mean diameter of the 100 tallest trees) were $41.4-44.9 \mathrm{~cm}$. The tree numbers were 639-926 trees per ha, the stand basal area of the stands was $54.0-60.1 \mathrm{~m}^{2} \mathrm{ha}^{-1}$, the standing stem volume was $802-981 \mathrm{~m}^{3} \mathrm{ha}^{-1}$, and the mean periodic volume growth (1998-2016) was 19.4-26.3 $\mathrm{m}^{3} \mathrm{ha}^{-1} \mathrm{year}^{-1}$.

All plots were repeatedly moderately thinned from above in the longer past. The strength, kind, and timing of thinning were similar on all included plots. After the first inventory in 1994, the stands developed under self-thinning conditions.

\section{Sample tree characteristics}

I examined 69 mature Norway spruces and European beeches, with approximately half of them in the control plots and the other half in the treatment plots (Table 1). In spring 2014 , before the start of water retention, the stem diameters of Norway spruce were 4-6 cm higher than that of European beech, and the intra-specific differences were minor. The stem diameter growth $\overline{i d}_{2009-2013}$ in the 5 years before water retention was similar in the control and treatment plots. Specifically, growth losses of $48 \%$ for the spruce and $36 \%$ for the beech in the drought period compared with the pre-drought reference period 2009-2013.

\section{Metrics for competition at present and tree growth in past}

\section{Competition index}

To quantify the competitive status of the sample trees, I calculated their competition index according to Hegyi (1974) at the beginning of the considered experimental drought period of the treated trees from 2014 to 2018. I used this commonly applied index, $c i_{j}=\sum_{\substack{i=1 \\ i \neq j}}^{n}\left(d_{i} / d_{j} \times 1 / d s t_{i j}\right)$, mainly based on tree diameter. This index quantifies the competition of central tree $\mathrm{j}$ based on the stem diameter of tree $\mathrm{j}$ $\left(d_{j}\right)$, the stem diameters of its neighbours (n) $d_{i, i=1 \ldots n}$, and the distance $\left(d s t_{i j}\right)$ between the central tree $\mathrm{j}$ and the respective neighbours. As the search radius for selecting the $\mathrm{n}$ of the central tree with $d_{j}$, I derived a species-specific function based on the stem diameters and crown radii on the experimental plots. Using linear regression, I derived $c r=e^{(-1.8020+0.7173 \times \ln (d))}$ for Norway spruce and $c r=e^{(-2.0479+0.9213 \times \ln (d))}$ for European beech. These functions reflect the mean tree crown radius,
Table 1 Overview of 69 sample trees from water retention experiment KROOF included in this study

\begin{tabular}{|c|c|c|c|c|c|}
\hline \multirow[t]{2}{*}{ Variable } & \multirow[t]{2}{*}{ Unit } & \multicolumn{2}{|c|}{ Norway spruce } & \multicolumn{2}{|c|}{ European beech } \\
\hline & & Control & Treatment & Control & Treatment \\
\hline $\mathrm{n}$ & trees & 18 & 17 & 19 & 15 \\
\hline$d_{1.3}$ spring 2014 mean & $\mathrm{cm}$ & 36.9 & 35.9 & 30.4 & 30.6 \\
\hline$d_{1.3}$ spring 2014 std & $\mathrm{cm}$ & \pm 6.0 & \pm 7.4 & \pm 8.9 & \pm 10.6 \\
\hline$d_{1.3}$ spring $2014 \mathrm{~min}$ & $\mathrm{~cm}$ & 28.4 & 23.5 & 18.8 & 13.3 \\
\hline$d_{1.3}$ spring $2014 \max$ & $\mathrm{cm}$ & 50.1 & 49.3 & 52.7 & 47.7 \\
\hline$\overline{i d}_{2009-2013} \pm$ std & mm year $^{-1}$ & $3.36 \pm 1.49$ & $3.75 \pm 1.99$ & $1.76 \pm 1.17$ & $1.79 \pm 1.39$ \\
\hline$\overline{i d}_{2014-2018} \pm$ std & $\mathrm{mm}_{\text {year }}{ }^{-1}$ & $1.98 \pm 1.06$ & $1.03 \pm 0.62$ & $1.69 \pm 1.27$ & $1.08 \pm 0.75$ \\
\hline
\end{tabular}

$\mathrm{N}$, number of sample trees; $d_{1.3}$, stem diameter at breast height; $\overline{i d}_{2009-2013}$, mean annual stem diameter growth in the 5 years before water retention; $\overline{i d}_{2014-2018}$ mean annual stem diameter growth in the 5 years during water retention treatment plots. min, Minimum; max, maximum; std, standard deviation 
depending on the stem diameter. Variable cr was multiplied by factor $1.75(r=c r \times 1.75)$ to include the most competitive $\mathrm{n}$ in the calculation of $c i_{j}$. Thus, all $\mathrm{i}=1 \ldots \mathrm{n}$ trees around central tree $\mathrm{j}$ with a distance of $d s t_{i j}<r_{j}$ were included in the calculation $c i_{j}$. Test runs with factors $1.5,1.75,2.0$, and 2.5 yielded an inclusion of $3.92,5.35,7.13$, and $10.99 \mathrm{n}$ on average. I decided to apply factor 1.75 for our analyses as a tree usually has 5-6 most impactful n (Prodan 1968a, b).

\section{Metrics for characterising trees' past course of growth}

This study's objective was to characterise tree-ring patterns and structures that may have functional implications for future tree growth under stress. For example, a strong inter-annual variation in tree ring width may indicate variations in growing conditions and the need for physiological and morphological acclimation of the crown and root at the expense of stem growth and reserve pools (Pretzsch 2021a). The early culmination of ring width and more narrow rings later (degressive course of growth) may indicate decreasing water conductance with increasing tree age. Conversely, a slow beginning and later culmination of ring width (progressive course) may improve water conductance growth and drought resilience at advanced ages (Pretzsch 2021b). The frequency of low growth years may indicate the frequency of embolism in the xylem, progressive emptying of the tree's reserve pool in the past, and reduced stress resilience at present and the future. Hence, I developed metrics to determine relationships between past growth manifested by structure and current growth (Table 2).

cvar: Based on the mean periodical diameter increment $(\overline{i d})$ in the past survey periods, the coefficient of variation $c v a r=s d_{i d} / \overline{i d}$ was calculated using the standard deviation $\left(s d_{i d}\right)$ and mean $(\overline{i d})$ of the annual id values. The more irregular the ring width pattern of a tree, the higher the cvar (Fig. 1a).

freq: The frequency of low growth years ( freq) was calculated as the number (n) of years with low diameter increment in a period (p). The criterion for low growth was an annual increment below the mean annual diameter increment minus twice the standard deviation of the annual diameter growth $\left(i d<\left(\overline{i d}-2 \times s d_{i d}\right)\right.$. The ratio freq $=n / p$ multiplied by 100 reflects the number of low growth years in one hundred years (Fig. 1b).

$h s t$ : The half-size time ( $h s t$ ) was calculated to quantify whether the past course of diameter development of

Table 2 Overview of metrics used in this study to characterise individual trees' past development and present state

\begin{tabular}{|c|c|c|}
\hline Variables' and metrics' names & Abbreviation & Explanation and indication \\
\hline Stem diameter & $\mathrm{d}$ & Indication of tree present size \\
\hline Tree height & $\mathrm{h}$ & Indication of tree present size \\
\hline Crown radius & $\mathrm{cr}$ & $\overline{c r}=\sqrt{\left(r_{1}^{2}+r_{2}^{2}+\ldots+r_{8}^{2}\right) / 8}$ \\
\hline Crown length & $\mathrm{cl}$ & $c l=h-h c b$ \\
\hline Crown projection area & сра & $c p a=\overline{c r}^{2} \times \pi$ \\
\hline Crown volume & $\mathrm{cv}$ & $c v=c l \times c p a$ \\
\hline Annual stem diameter increment & id & $\mathrm{id}=$ sum of ring width in $\mathrm{N}$ and $\mathrm{E}$ direction in a given year \\
\hline Coefficient of variation of id & cvar & $\begin{array}{l}\text { Inter-annual variation of id, } c v a r=s d_{i d} / \overline{i d} \text {, indicates the smoothness/oscillation } \\
\text { of the id trajectory }\end{array}$ \\
\hline Frequency of low growth years & freq & Number of years, $\mathrm{n}$, in period $\mathrm{p}$ with low growth id, $i d<\left(\overline{i d}-2 \times s d_{i d}\right)$ \\
\hline Half-size time & hst & $\begin{array}{l}\text { Describes whether d developed in a period degressively }(\mathrm{hst}<0.5), \text { linearly }(\mathrm{hst} \cong \\
0.5) \text {, or progressively }(\mathrm{hst}>0.5) \text {. It refers to the relative time }(t=0 \ldots 1) \text { when } \\
d_{h}=\left(d_{e}-d_{b}\right) / 2 \text { is reached }\end{array}$ \\
\hline Relative range of id & rng & $\begin{array}{l}\text { Indicates the relative amplitude of id in a given period, } r n g=(\text { maxid }- \text { minid }) / \overline{i d} \\
\text { with maxid and minid the maximum and minimum id values }\end{array}$ \\
\hline Standard deviation of id & sd & Indicates the absolute variation of id, with $68 \%$ of the id values within $\overline{i d} \pm s d_{i d}$ \\
\hline Mean id in the past & mipre & Mean level of annual diameter increment $\overline{i d}$ in the past before the drought event \\
\hline Competition index according to Hegyi (1974) & ci & $\begin{array}{l}c i_{j}=\sum_{i=1, i \neq j}^{n}\left(d_{i} / d_{j} \times 1 / \text { dist }_{i j}\right), \mathrm{d}_{\mathrm{j}}, \mathrm{d}_{\mathrm{i}, \mathrm{i}=1 \ldots \mathrm{n}}, \text { stem diameter of central tree } \mathrm{j} \text { and } \\
\text { neighbour } \mathrm{i}, \text { dist }=\text { distance between trees } \mathrm{i} \text { and } \mathrm{j}\end{array}$ \\
\hline Mean id in the current growth period & mipost & Mean level of annual diameter increment in the current growth period $\overline{i d}$ \\
\hline
\end{tabular}

The metrics for characterising the past were based on the annual diameter increments (id) and tree diameter (d). The metrics for n-years old trees can be calculated for any defined imprinting period in the past 
Fig. 1 Metrics cvar, freq, hst, rng, sd, mipre for characterising past annual stem diameter growth of trees in 1984-2013 visualised for selected Norway spruces underlying this study. To visualise the latter measures' indicative value, I selected trees from the lower (thin trajectories) and upper range (bold trajectories) of the respective values. The vertical lines reflect the beginning and end of the reference period for characterising past growth
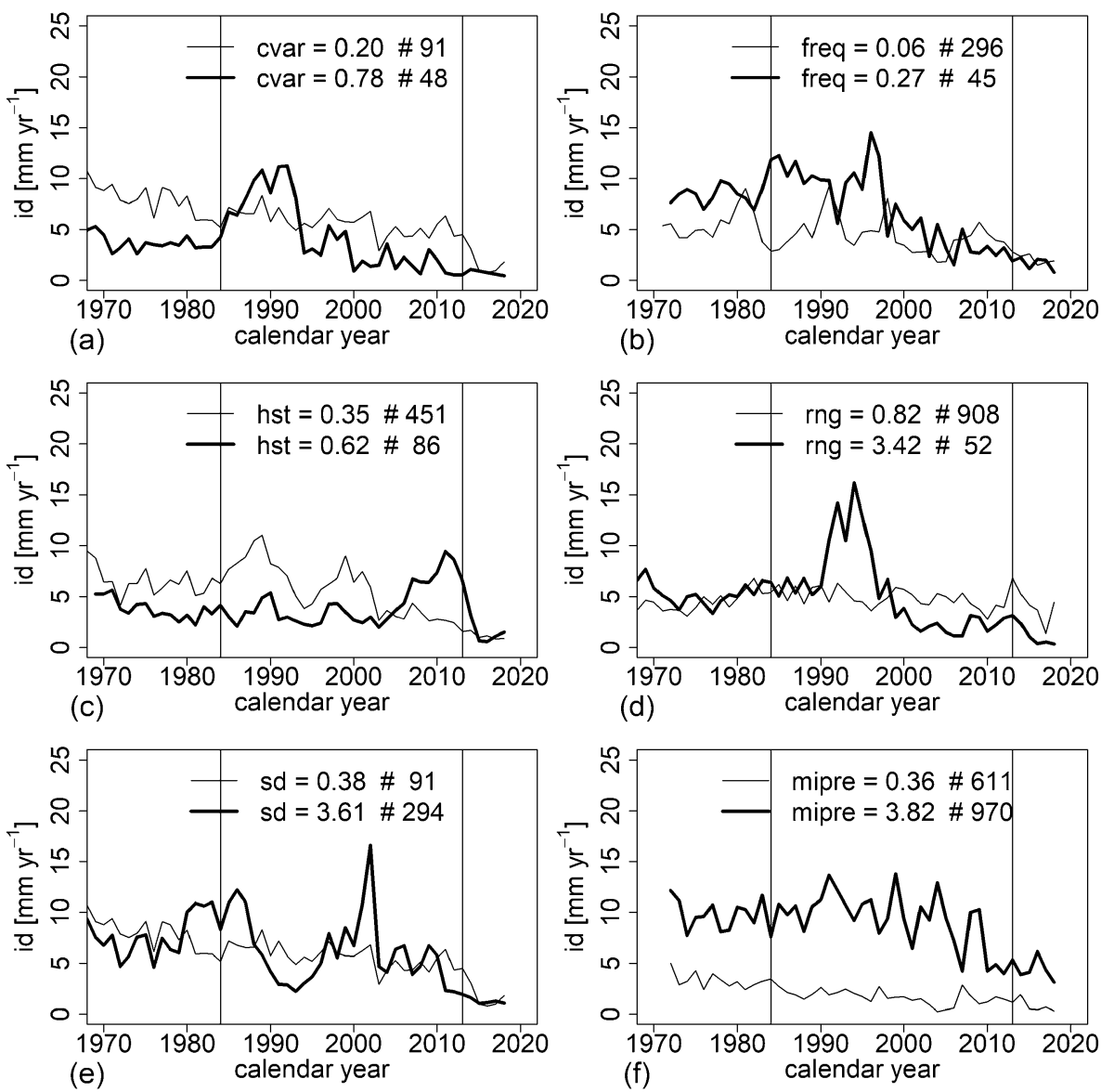

the tree was degressive, linear, or progressive. I quantified the respective pattern by the $h s t$ at which the tree achieved half of the size growth from the beginning to the end of the respective growth $\mathrm{p}$. For this purpose, the length of $\mathrm{p}$ was set to 1.0, and I calculated the point of time between the beginning and the end of the tree, arriving at half the size growth $\left(d_{h}=\left(d_{e}-d_{e}\right) / 2\right)$ it achieved in the whole period.

The trajectory of quick starters with degressive development is indicated by low hst values, as half of the diameter in a period is achieved early (Fig. 1c). Latecomers are indicated by high hst values, as they follow progressive courses of growth and reach the highest late. Continuous linear development would result in $h s t=0.5$.

rng: The relative range of annual diameter increment was calculated as $r n g=($ maxid - minid $) / \overline{i d}$, with maxid and minid as the maximum and minimum diameter increment, respectively, and $\overline{i d}$ as the mean diameter growth in the $\mathrm{p}$. Thus, rng is a measure of the relative amplitude of the diameter growth and characterise the maximum deflection of the growing conditions in a period. These metrics reflect the instability of growth and underlying environmental conditions (Fig. 1d). $s d$ : Standard deviation of the id values in a period; in addition to cvar, an absolute metric that indicates that $68 \%$ of the id values lie within the range $\overline{i d} \pm s d_{i d}$ (Fig. 1e).

mipre: Mean annual diameter increment $\overline{i d}$ in the past before the start of the drought event (Fig. 1f).

To visualise the indicative value of the past course of growth measures, I selected Norway spruces from the lower and upper third of the respective measures range (Fig. 1). The metric cvar indicates a low coefficient of variation of the diameter increment for tree no. 91, which follows a relatively constant downward trend compared to the stronger oscillating course of no. 48 with a high coefficient (Fig. 1a). Tree no. 45 had a much higher frequency of low growth years than tree no. 296 (Fig. 1b). Tree no. 451 demonstrated a downward trend compared to no. 86, which displayed the highest growth in the second half (1984-2013) (Fig. 1c). The relative amplitude was low for tree no. 908 and high for tree no. 52, as the latter had high growth and low growth phases in the middle of the reference period (Fig. 1d). The standard deviation was low for tree no. 91, which followed a shallow course of growth and high for no. 294, reflecting an alternation of years and periods with low and high growth rates (Fig. 1e). Figure 1f displays that the dataset includes trees with low and high mean growth rates in the 30 years. 
Table 3 Overview of basic data for scrutiny of research questions Q1-Q3

\begin{tabular}{|c|c|c|c|c|c|}
\hline \multirow[t]{2}{*}{ Variable } & \multirow[t]{2}{*}{ Unit } & \multicolumn{2}{|c|}{ Norway spruce } & \multicolumn{2}{|c|}{ European beech } \\
\hline & & Mean & std & Mean & std \\
\hline d & $\mathrm{cm}$ & 36.45 & 6.49 & 30.50 & 9.39 \\
\hline $\mathrm{h}$ & $\mathrm{m}$ & 32.04 & 2.00 & 28.46 & 3.06 \\
\hline cr & $\mathrm{m}$ & 2.17 & 0.28 & 3.00 & 0.85 \\
\hline $\mathrm{cl}$ & $\mathrm{m}$ & 13.39 & 3.64 & 12.07 & 4.07 \\
\hline ci &.$/$ & 1.32 & 0.68 & 2.46 & 0.77 \\
\hline cvar &.$/$ & 0.44 & 0.14 & 0.51 & 0.24 \\
\hline freq & year $^{-1}$ & 0.16 & 0.05 & 0.15 & 0.06 \\
\hline hst &.$/$ & 0.39 & 0.08 & 0.37 & 0.10 \\
\hline rng &.$/$ & 1.67 & 0.45 & 1.86 & 0.83 \\
\hline sd & mm year $^{-1}$ & 2.15 & 0.89 & 1.33 & 0.56 \\
\hline mipre & mm year $^{-1}$ & 4.97 & 1.61 & 3.13 & 1.52 \\
\hline mipost & mm year $^{-1}$ & 1.54 & 0.98 & 1.43 & 1.09 \\
\hline
\end{tabular}

Mean values (mean) and standard deviations (std) demonstrated for 1984-2013 and separately for Norway spruce and European beech. For variable explanations, see Table 2

\section{Reference periods for calculating metrics}

The introduced metrics for the trees' past development (Fig. 1, Table 2) were calculated for different periods. To receive stable metrics, a period of at least 5 years from 2013 to 2009 was chosen. In the following steps, I extended the period in 1-year steps, namely 2013-2008, 2013-2007, etc. The respective metrics resulted in cvar $_{2009-2013}$ cvar $_{2008-2013} \ldots$ cvar $_{2007-2013}$ and more than 30 years backwards. Hence, I could analyse any changes in the correlation between the trajectory characteristics such as cvar and hist and the growth in 2014-2018. For the characterisation of the database (Table 3 ), the metrics were calculated for 1984-2013 (Fig. 2). Most of the time series returned to 1950-1970 (Fig. 3).

\section{Statistical evaluation}

\section{Analysing correlation between past growth pattern and current growth}

The metrics cvar, freq, hst, rng, sd, and mipre were correlated with the current growth to scrutinise how the course of growth in the past determines the current drought stress response. The mean annual diameter increment quantified the current growth during experimental drought stress from 2014 to 2018. The metrics for the course of growth in the past were calculated for various periods to determine the duration of the memory effect by analysing the development of the correlation coefficient with increasing backward extension of the reference period. I calculated the correlation between the growth $\overline{i d}_{2014-2018}$ and the metrics starting with the 5 years 2013-2009, proceeding with 6 years 2013-2008 until 50 years 2013-1964.

\section{Mixed effect models for estimating current growth depending on present and past tree characteristics}

To analyse how the diameter growth in 2014-2018 was determined by the treatment and the present state and past development of the trees, I applied linear mixed models with a random effect at the plot level to account for spatial autocorrelation effects. The fixed effect variables, such as experimental factors (water retention vs. control), stem diameter, competition index, and metrics of the past tree growth, represented the influence of the trees' present and past characteristics on its growth; the parameters covered the fixed effects by $a_{0}-a_{n}$. The random effects on $a_{0}$ (intercept) at the plot level considered any spatial (several trees per plot) autocorrelations. The random effect $b_{i}$ covered the level plot. The indices $\mathrm{i}$ and $\mathrm{k}$ in the following equations refer to the plot and single observation levels, respectively. In all models, the random variable $b_{i}$ accounts for the correlation between the trees on plot $\mathrm{i}$.

i described the respective model alternatives and selected the variable combinations based on the RMSE and AIC criterion (Akaike 1981). The following model numbers refer to the results in the text and tables (Models 1-4).

Model 1

$\overline{i d}_{i k}=a_{0}+a_{1} \times d_{i k}+b_{i}+\varepsilon_{i k}$

This model was used as a baseline. It represents the effect of the initial tree diameter (d) in spring 2014, only on the mean annual growth $(\overline{i d})$ in the 2014-2018 treatment.

Model 2

$\overline{i d}_{i k}=a_{0}+a_{1} \times d_{i k}+a_{2} \times$ treat $_{i}+b_{i}+\varepsilon_{i k}$

This model represents the effect of initial size and treatment on growth $\overline{i d}$ during the treatment period.

Model $3 \mathrm{a}$ and $\mathrm{b}$.

The underlying model 3 was for Norway spruce

$$
\begin{aligned}
\overline{i d}_{2014-2018_{i k}}= & a_{0}+a_{1} \times \text { treat }_{i}+a_{2} \times c i_{i k}+a_{3} \times c r_{i k} \\
& +a_{4} \times c l_{i k}+b_{i}+\varepsilon_{i k}
\end{aligned}
$$

and for European beech

$\overline{i d}_{2014-2018_{i k}}=a_{0}+a_{1} \times$ treat $_{i}+a_{2} \times c r_{i k}+b_{i}+\varepsilon_{i k}$.

These models represent the effect of initial size and other additional characteristics of the tree and treatment on growth during the treatment period.

Model 4a and $\mathrm{b}$.

The underlying model 4 was for Norway spruce 
Fig. 2 Courses of annual stem diameter increment of $\mathbf{a}, \mathbf{b}$ Norway spruce and $\mathbf{c}, \mathbf{d}$ European beech based on this study. The control trees are represented by solid lines, the treatment trees by broken lines. The left solid vertical line represents the beginning of the 30 -years (1984-2013), the right solid line represents the end of the reference period and the beginning of the 5-year experimental drought (2014-2018). The two vertical broken lines indicate the drought years 1976 and 2003 (left and right, respectively)
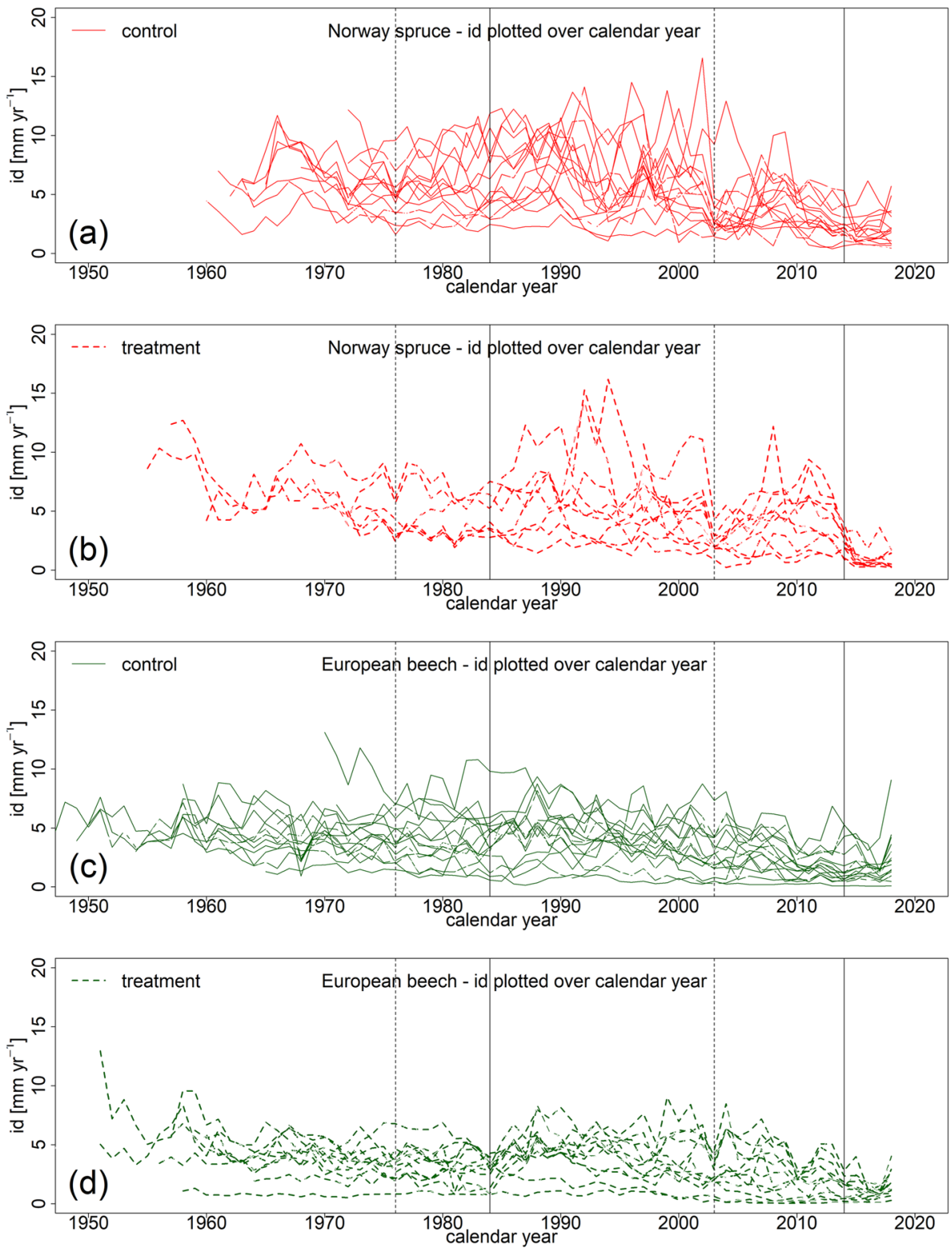

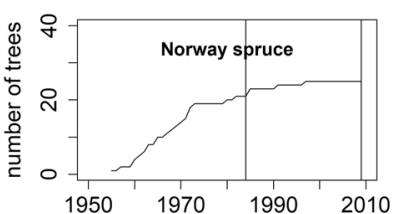

(a) calendar year

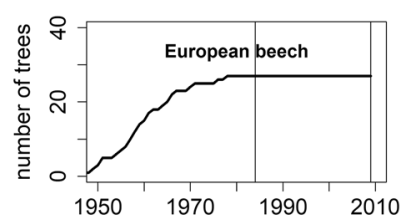

(b) calendar year
Fig. 3 Number of annual stem growth records plotted over calendar year for a Norway spruce and $\mathbf{b}$ European beech. The vertical lines represent 1984-2009 selected to calculate the metrics cvar, freq, hst, rng, sd, and mipre

$$
\begin{aligned}
\overline{i d}_{2014-2018_{i k}=} & a_{0}+a_{1} \times d_{i k}+a_{2} \times \text { treat }_{i}+a_{3} \times \text { cvar }_{i k} \\
& +a_{4} \times c i_{i k}+a_{5} \times c v_{i k}+b_{i}+\varepsilon_{i k}
\end{aligned}
$$

$\overline{i d}_{2014-2018_{i k}}=a_{0}+a_{1} \times$ treat $_{i}+a_{2} \times$ cvar $_{i k}+b_{i}+\varepsilon_{i k}$.

In addition to the current tree characteristics and the treatment, these models consider metrics of the tree development of the past, namely metrics derived for indicating the ecological memory.

The selection of the fixed effects variables and random effects on the intercept at the plot level was based on AIC comparisons, resulting in Models 2-4. For all calculations, I used the statistical software R 3.6.3 (R Core Team 2017), and I used the libraries nlme (Pinheiro et al. 2018), lme4 (Bates et al. 2015), lmerTest (Kuznetsova et al. 2017), and MuMIn (Barton 2009).

and for European beech 


\section{Results}

\section{Quantitative basis of study and visualisation of the growth trajectories}

To characterise the 35 Norway spruces and 34 European beeches included in this study, I calculated the stem diameter, tree height, crown radius, crown length, and competition index, in 2014 before the beginning of the water retention on the treatment plots. The characteristics of the growth pattern in the past, cvar, freq, hst, rng, sd, and mipre were calculated for 1984-2013 (Table 3). As I also calculated the measures for other periods in time, I will also call them cvar $_{1984-2013}$, fre $q_{1984-2013}, \ldots, s d_{1984-2013}$ in the text for clarification. The mean id were calculated for 1984-2013 before the beginning of the water retention (mipre ${ }_{1984-2013}$ ) and for 2014-2018 (mipost), which represents the growth under drought stress on the treatment plots and the reference on the control plots.

The visualisation of the annual stem diameter increment (Fig. 2) reveals a stronger inter-annual variation in Norway spruce (a) than in (b) European beech. While Norway spruce displays a generally decreasing trend since the 1990s, European beech continues to develop relatively parallel to the $\mathrm{x}$-axis. This results from the general species-specific faster increases, earlier culmination, and decreased spruce growth compared with beech. Norway spruce appears stronger affected by the past drought years (e.g. 1976, 2003) compared with beech. Beyond the drought years, the ups and downs of tree growth in the past are likely caused by thinning in the longer past; after plot establishment in 1994, the stands developed under self-thinning conditions.

There were no systematic differences between the control and treated trees' growth before the start of water retention in 2014 (Supplementary Figure 2a and b). However, there were clear differences between the groups within the water retention period. Particularly, the growth of the treated Norway spruces decreased strongly in the first 2-3 years, and then, both species did not further decrease in growth but stabilised at a reduced level. However, the water retention continued until 2018, at the end of the displayed trajectories.

The following correlation analyses refer to the trees' past growth from 1984. For the Norway spruce, $90 \%$ of the trees covered this period, while all beech trees covered this period. The main reasons for the incomplete time series in the longer past were disturbances of tree ring patterns by branches, rots, or resin pockets. I did not want to core the trees more than twice to avoid spoiling the stem or trigger artefacts in the ongoing experiment. Norway spruces were generally approximately 20 years younger than beeches (see "Description of stand and tree characteristics" section); therefore, even cores that matched the pith were shorter regarding years than cores from beeches.

\section{Analysing duration of ecological memory effect on current tree growth}

Results are displayed for Norway spruce and European beech in the same graph to compare the species-specific patterns (Fig. 4). The left ends of the correlation trajectories should be neglected, as they may be distorted due to the decreasing number of trees covering the calendar years in the past.

The coefficient of variation of cvar was negatively correlated with $\overline{i d}_{2014-2018}$ over a long period in the past. The higher the id variation in the last 30-40 years, the lower the growth in the drought period (Fig. 4a). Interestingly, the higher the frequency of extreme low growth years in the last 20 years, the better the growth in $\overline{i d}_{2014-2018}$ (Fig. 4b). European beech displayed a higher positive correlation between hst and growth (Fig. 4c), and the correlation increased the further the reference period reached backwards. This indicates, especially for beech, that latecomers performed better in drought years than quick starters. The reaction pattern of metric ng was similar to that of cvar (Fig. 4d). Regarding the sd and mipre (Fig. 4e, f), Norway spruce and European beech behaved similarly. Both measures demonstrated a positive correlation $\overline{i d}_{2014-2018}$ in the last 20-30 years. The latter refers mainly to a size effect; namely, the higher the standard deviation and the absolute stem diameter increment in the previous period, the higher the growth rate in $\overline{i d}_{2014-2018}$.

Interestingly, in certain cases, a couple of years shorter or longer did not yield vastly different results and the correlation between cvar, freq, hst, rng, sd, and mipre and $\overline{i d}_{2014-2018}$ growth was relatively stable. For instance, for cvar, I found several disjointed periods in the longer past between 1950 and 1960, with high correlations but no significant correlations in periods just one or two years longer or shorter. Conversely, 1970-1990 provided consistently similar high coefficients for the metrics cvar and hst (Fig. 4a, c). Therefore, to detect reliable and stable reference period lengths, I selected periods with continuously significant correlations. Based on these criteria, the following periods of metricsspecific periods were chosen to characterise the trees' past (Fig. 4). For cvar, I chose 1980-2013 (last 33 years), for freq 1995-2013 (last 19 years), hst 1980-2013 (last 33 years), rng 1980-2013 (last 33 years), sd 2005-2013 (last 9 years), and mipre 1995-2013 (last 19 years).

\section{Correlation between various metrics of ecological memory effect}

Several metrics strongly correlate with each other: in the 30 -year imprinting period cvar with freq, hst, rng. This correlation was mostly stronger when using metrics-specific imprinting periods. Regarding most metrics, Norway spruce and European beech behaved similarly. 
Fig. 4 Pearson correlation coefficient between stem diameter growth in 2014-2018 and selected metrics for trees calculated for 2009-2013 (vertical line) and its change with reference periods reaching back into past (2009-2014...20091950). The results are displayed for Norway spruce (thin lines) and European beech (bold line) separately for six selected measures a cvar, b freq, $\mathbf{c}$ hst, $\mathbf{d}$ rng, e sd, and $\mathbf{f}$ mipre. The bold grey and black horizontal lines display for Norway spruce and European beech, respectively, the reference periods the metrics for the regression analyses in "Contribution of past to estimation of current tree growth" section were based on. The strong oscillation of the trajectories before 1970 results from decreasing sample sizes (Fig. 3). The periods that resulted in significant correlations $(p<0.05)$ are indicated by "*" on the trajectories of the correlation coefficients
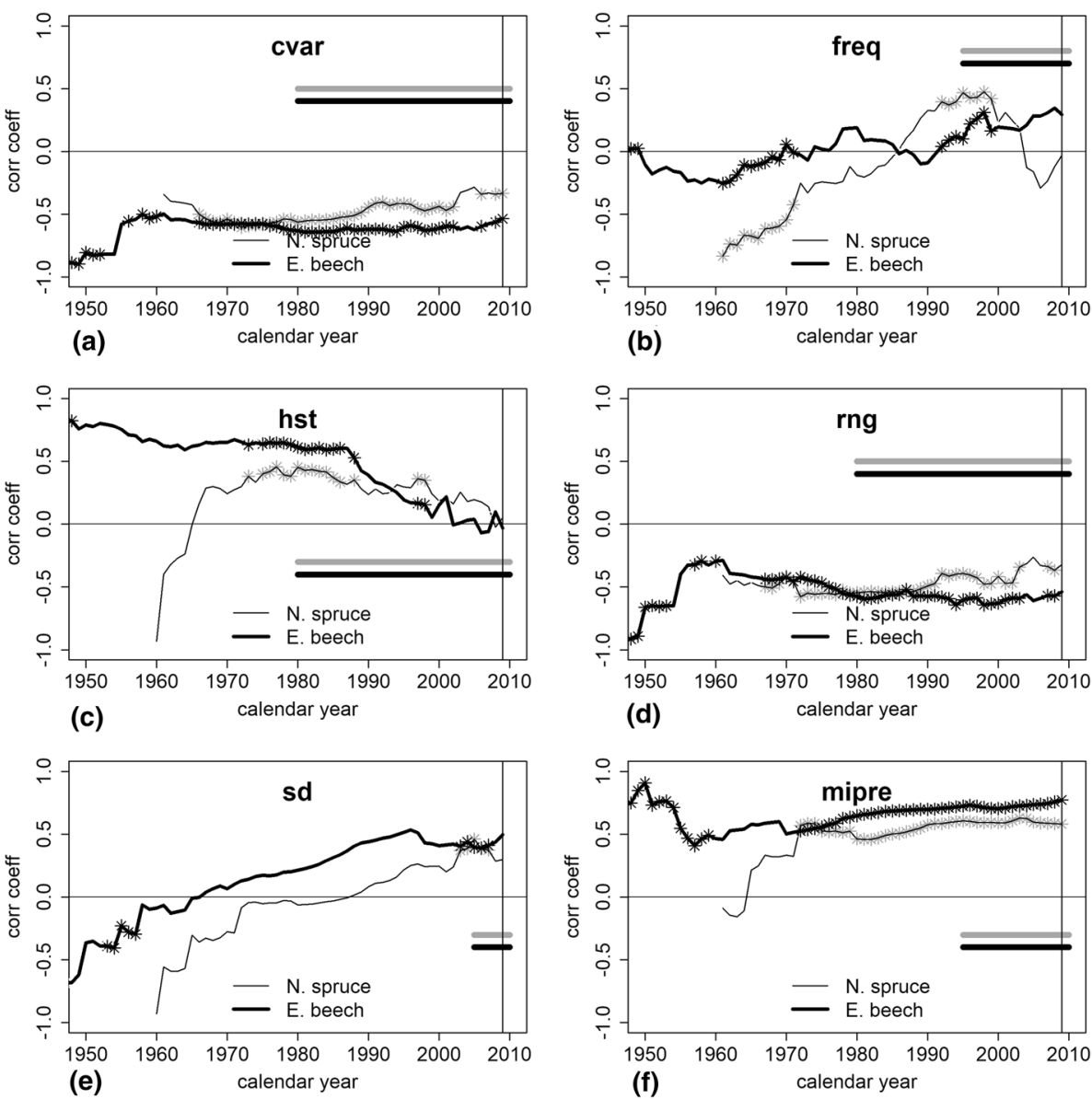

The comparison between the matrixes based on 30 years to the correlation metrics-specific periods revealed that, based on the shorter past, sd and freq had a strong and opposite effect (positive correlation with mipost) compared with $\mathrm{cv}$ and rng, which represent the variation in the longer past (negative correlation with mipost). Strong inter-annual variation appears to be detrimental to growth in the long term. However, dry years in the recent past may prime the preparation of trees for stress. These findings suggest that long- and short-term effects may be integrated into the subsequent modelling approaches to examine ecological memory relevance.

For the Norway spruce, mainly cvar, rng, and hst were correlated with each other; namely, trees with a strong variation in annual diameter increment also have a wide range between the highest and lowest growth rates and display a progressive course of growth. Cvar is the variable with the maximum correlation with most other metrics.

For the European beech, cvar, rng, and hst were even closer correlated; however, there were more correlations between the different measures of the trees' past. For instance, cvar was also significantly negatively correlated with mipre, and hst was positively correlated with mipre. Here, cvar, hst, and rng are the variables with the maximum correlation with the three other variables. This reflects a much higher interdependency between the different measures for beech and higher redundancy of the set of measures than spruce (Fig. 5).

\section{Contribution of past to estimation of current tree growth}

The statistical characteristics of the growth prediction for Norway spruce and European beech with and without the inclusion of information of the trees' past are demonstrated using Models 1 and 4 (Tables 4, 5). For the characteristics of Models 2 and 3, the details are presented in Supplementary Tables 1 and 2. Table 6 summarises the stepwise model improvement for all four models and both species, starting with baseline Model 1 and progressing to Model 4. In all the tables, the results were restricted to the characteristics of the fixed effects.

Table 6 demonstrates that all three model characteristics, AIC, $\mathrm{R}^{2}$, and RMSE, can be improved by several percentages 


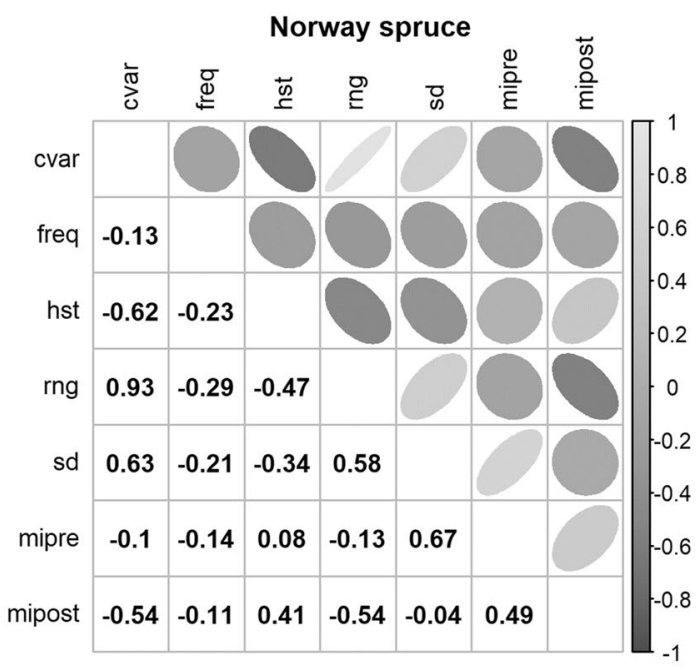

(a)

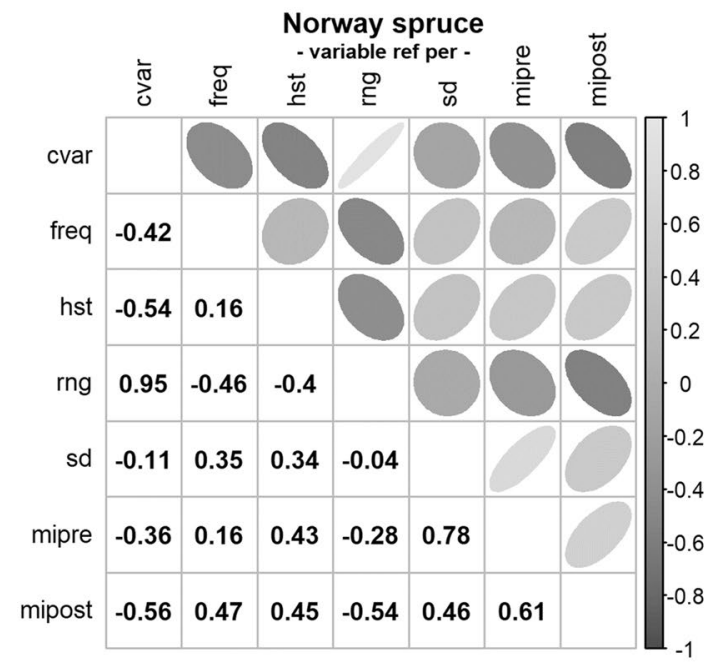

(c)

Fig. 5 Correlation between various metrics for past tree growth (cv, freq, hst, rng, sd, and mipre) and present growth (mipost) for Norway spruce and European beech. a, b Metrics calculated for the 30-years imprinting-period 1984-2013. c, d Metrics based on the lengths of imprinting periods with the best correlation with the present growth (cvar 1980-2013, freq 1995-2013, hst 1980-2013, rng 1980-2013,

compared with the baseline model. Thus, past growth metrics' inclusion strongly contributed to a further improvement of the stem diameter growth prediction, especially for European beech.

I also looked for any interactions between the treatment and the metrics characterising the trees' past, as I assumed that past growth may be more relevant for trees that had dried out. However, no significant interaction between treatment and cvar, hst, or sd indicates the strong overarching effect of the antecedent growing conditions on the behaviour of both control and treated trees.

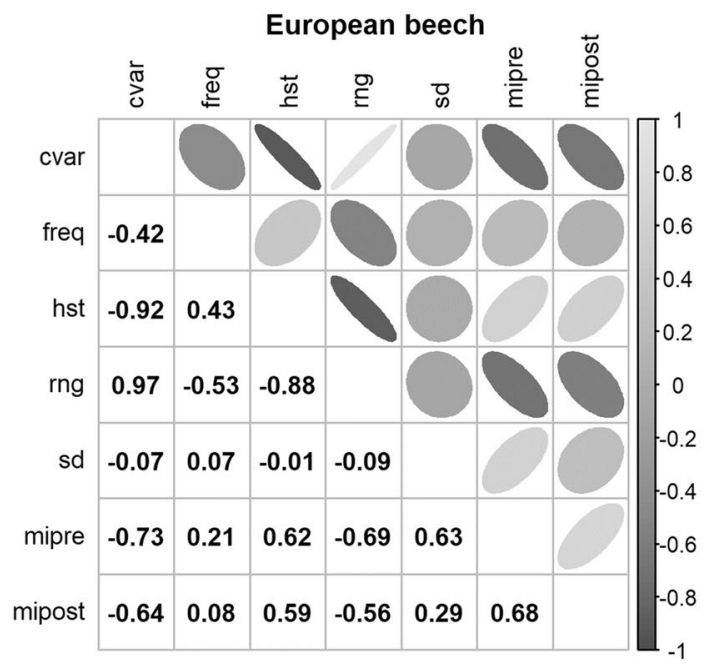

(b)

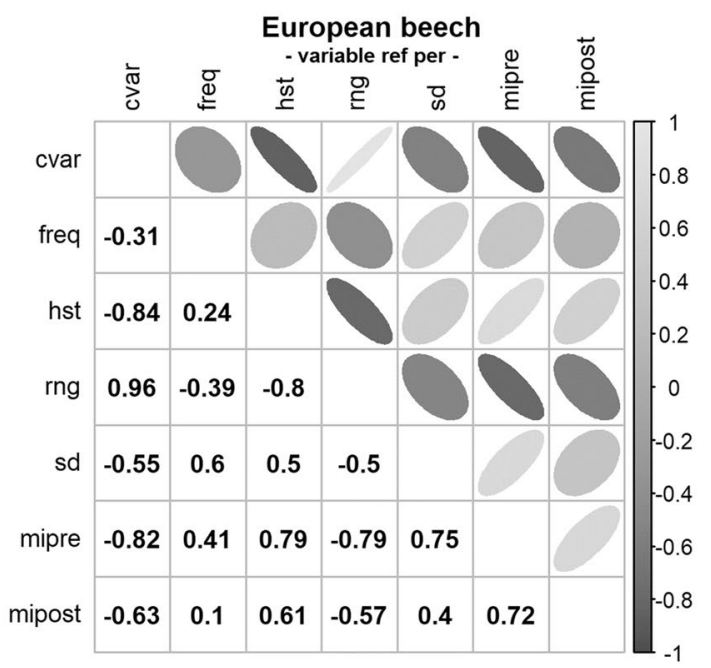

(d)

sd 2005-2013, and mipre 1995-2013). The correlation matrices are displayed in the left part of the Pearson correlation coefficients and in the right part the strength of the correlation (wide ovals =low, narrow ovals = strong correlation) and the sign of the correlation are visualised (downward = negative, upward = positive correlation). For levels of significance of Pearson's r, see Supplementary Figure 3

\section{Discussion}

\section{Tree development in past codetermines drought stress behaviour at present}

This study revealed that past stem diameter growth reflects the tree ring pattern in the stem and growth history of the trees over several decades. The trend and inter-annual growth variation have stored information on past individual growing conditions. The ring width reflects only the result of the respective growing conditions and provides 
Table 4 Results of fitting linear mixed effect model of mean tree diameter increment in 2014-2018 depending on tree diameter at the beginning of spring 2014
Table 5 Results of fitting linear mixed effect model of mean tree diameter increment in 2014-2018 depending on tree diameter at the beginning of spring 2014 and trees' treatment (water retention $=1$, control $=0$ )

\begin{tabular}{|c|c|c|c|c|}
\hline Fixed effect variable & Fixed effect parameter & Estimate & Std. Error & $p$ \\
\hline \multicolumn{5}{|c|}{ (a) Norway spruce and number of observations, $n=35$} \\
\hline intercept & $a_{0}$ & -0.7855 & 0.7011 & 0.2741 \\
\hline \multirow[t]{2}{*}{$\mathrm{d}$} & $a_{1}$ & 0.0650 & 0.0181 & 0.0016 \\
\hline & Random effect & Std. Dev & & \\
\hline \multirow[t]{3}{*}{ Tree level } & $b_{i}$ & 0.6318 & & \\
\hline & Residuals & Std. Dev & & \\
\hline & $\varepsilon_{i k}$ & 0.6675 & & \\
\hline \multicolumn{5}{|c|}{ (b) European beech, number of observations: $n=36$} \\
\hline intercept & $a_{0}$ & 0.0402 & 0.5938 & 0.9467 \\
\hline \multirow[t]{2}{*}{ d } & $a_{1}$ & 0.0454 & 0.0183 & 0.0219 \\
\hline & Random effect & Std. Dev & & \\
\hline \multirow[t]{3}{*}{ Tree level } & $b_{i}$ & 0.2955 & & \\
\hline & Residuals & Std. Dev & & \\
\hline & $\varepsilon_{i k}$ & 0.9799 & & \\
\hline
\end{tabular}

Model $1 \overline{i d}_{i k}=a_{0}+a_{1} \times d_{i k}+b_{i}+\varepsilon_{i k}$ was used as a baseline model. AIC comparisons suggested using random effects at the plot leve

\begin{tabular}{|c|c|c|c|c|}
\hline Fixed effect variable & Fixed effect parameter & Estimate & Std. Error & $p$ \\
\hline \multicolumn{5}{|c|}{ (a) Norway spruce and number of observations, $n=35$} \\
\hline intercept & $a_{0}$ & 1.4261 & 0.8482 & 0.1083 \\
\hline d & $a_{1}$ & 0.0909 & 0.0256 & 0.0020 \\
\hline treat & $a_{2}$ & -0.8558 & 0.2658 & 0.0105 \\
\hline cvar & $a_{3}$ & -3.4478 & 0.8255 & 0.0005 \\
\hline ci & $a_{4}$ & -0.3524 & 0.1306 & 0.0138 \\
\hline \multirow[t]{2}{*}{$\mathrm{cv}$} & $a_{5}$ & -0.0040 & 0.0020 & 0.0518 \\
\hline & Random Effect & Std. Dev & & \\
\hline \multirow[t]{3}{*}{ Tree level } & $b_{i}$ & 0.3430 & & \\
\hline & Residuals & Std. Dev & & \\
\hline & $\varepsilon_{i k}$ & 0.4611 & & \\
\hline \multicolumn{5}{|c|}{ (b) European beech; number of observations: $n=36$} \\
\hline intercept & $a_{0}$ & 3.2694 & 0.3691 & 0.0001 \\
\hline treat & $a_{1}$ & -0.6465 & 0.2812 & 0.0443 \\
\hline \multirow[t]{2}{*}{ cvar } & $a_{3}$ & -3.0779 & 0.6188 & 0.0001 \\
\hline & Random Effect & Std. Dev & & \\
\hline \multirow[t]{3}{*}{ Tree level } & $b_{i}$ & 0.0004 & & \\
\hline & Residuals & Std. Dev & & \\
\hline & $\varepsilon_{i k}$ & 0.8137 & & \\
\hline
\end{tabular}

no information regarding the specific causes of individual development. However, it contains valuable unspecific information regarding the past that has become a structural and ecological memory.

The correlations between the present growth and growth in the recent or former past strongly suggest ecological memory effects. The metrics cvar and rng both indicate the degree of inter-annual variation in growth.

The variables cvar, rng, and hst represent a long-term ecological memory and indicate that, in the long term, low inter-annual variation and amplitude of variation alongside 
Table 6 Comparison of AIC, $\mathrm{R}^{2}$, and RMSE between Model 1 (baseline model $\overline{i d}=f(d)$ ), Model $2(\overline{i d}=f(d$, treatment)), Model 3 $(\overline{i d}=f(d$, treatment, tree state variables $))$, and Model $4(\overline{i d}=f(d$, treatment, tree state variables, metrics for the trees' past $))$

\begin{tabular}{|c|c|c|c|c|c|c|c|}
\hline \multirow{2}{*}{$\begin{array}{l}\text { Models } \\
1-4\end{array}$} & \multirow[t]{2}{*}{ abs/rel } & \multicolumn{3}{|c|}{ Norway spruce } & \multicolumn{3}{|c|}{ European beech } \\
\hline & & AIC & $\mathrm{R}^{2}$ & RMSE & AIC & $\mathrm{R}^{2}$ & RMSE \\
\hline \multirow[t]{2}{*}{ Model 1} & abs & 98.85 & 0.57 & 0.58 & 111.43 & 0.22 & 0.93 \\
\hline & rel & 100 & 100 & 100 & 100 & 100 & 100 \\
\hline \multirow[t]{2}{*}{ Model 2} & abs & 96.16 & 0.58 & 0.57 & 110.80 & 0.25 & 0.92 \\
\hline & rel & 97 & 102 & 98 & 99 & 114 & 99 \\
\hline \multirow[t]{2}{*}{ Model 3} & abs & 90.89 & 0.71 & 0.47 & 105.88 & 0.26 & 0.91 \\
\hline & rel & 92 & 125 & 81 & 95 & 118 & 97 \\
\hline \multirow[t]{2}{*}{ Model 4} & abs & 87.69 & 0.80 & 0.38 & 91.39 & 0.47 & 0.78 \\
\hline & rel & 89 & 140 & 66 & 82 & 214 & 84 \\
\hline
\end{tabular}

The model characteristics of the baseline model were set to $100 \%$ to reveal the additional explanatory contribution of attributes of the treatment, the tree present structure and constellation, and past development

AIC, Akaike information criterion according to Akaike (1981), corrected $\mathrm{R}^{2}$ (conditional $\mathrm{R}^{2}$ including random effects), and root-mean-square error RMSE (including random effects)

a progressive course of growth at a high level had a positive effect on tree growth.

I also found the following short-term ecological memory effect. I identified a second set of influential metrics, freq and sd, both had a positive effect on growth; the stronger the variation in the last few years and the higher the frequency of drought years in the recent past, the better the trees resisted extended drought. As the correlation with increasing backwards reaching timespans and reference periods was only slightly different for both species, I chose the same imprinting periods.

The minor effects of hst, mipre, and short-term memory may be explained by the high correlation between cvar and mipost. The lack of such data may be one reason why the long-term memory effect has been assumed (Camarero et al. 2018) and conceptually addressed (Ogle et al. 2015; Zweifel and Sterck 2018), but has not analysed. The growth explanation accuracy increased by adding further variables; however, the strongest improvement was the addition of past metrics. Past development had a stronger effect on present growth than the effect of water retention. I expected an interaction between the treatment and the metrics characterising the trees' past, as I assumed that past growth may be more relevant for trees that had dried out. Our unique dataset discovered this memory effect: a combination of long-term courses of growth, and detailed measurement of internal and external tree and crown characteristics. Including the different individual tree histories via the cvar metrics into the model explained an additional $20-30 \%$ of the growth variation between dried-out and control spruce and beeches. The linear mixed model calculations revealed for both species, especially beech, a considerable improvement of AIC, $\mathrm{R}^{2}$, and RMSE compared with the basic model based on initial diameter and treatment only. However, there were no significant interactions between treatment and cvar, hst, or sd, indicating antecedent growing conditions' overarching effect on both control and treated trees' behaviour.

\section{Past human and natural disturbances of trees reduces their drought stress resistance at present}

I harnessed the ecological memory of trees that underwent an extended experimental drought period embedded in their xylem as a tree ring structure. I found that mainly the longterm level and course of growth, the inter-annual variation in the long term, and the inter-annual variation in the short term affected present tree growth.

Strongly negative effects of the inter-annual variation of growth, represented by cvar and rng, may be caused by higher demands of photosynthates for repair and acclimation and a depletion of the tree's reserve pool in the past causing low resistance at present. High cvar values may indicate repeated embolies and disturbance of the inner pipeline system, increasing the susceptibility and predisposition to drought stress. The positive effect of growth variation and low growth years in the recent past may be caused by priming effects and preparing the trees to upcoming drought, termed eustress by Tesche (1992) for short-term positive effects. Dry years, especially on dry sites, can trigger the growth allocation to and the extension of roots (Nikolova et al. 2011; Pretzsch et al. 2012a,b). This may result in a better water accessibility of trees primed by antecedent drought events as assumed by Fleta-Soriano and MunnéBosch (2016). However, Backhaus et al. (2014) did not find such morphological legacies in their study of grassland communities. 
Progressive growth and high growth levels in the predrought period were beneficial for growth under drought conditions, consistent with Camarero et al. (2018). Advantageous water conductance of wide rings and large xylem vessels may explain this finding (Ryan and Yoder 1997; Hartmann 2011). A low hst value indicates fast juvenile growth, followed by smaller tree rings, suggesting narrow tree rings and low water conductance in comparison to higher hst values (Ryan and Yoder 1997).

Netzer et al. (2019) also addressed the ambivalent effect of past high growth rates on growth and drought resistance. Trees with larger xylem vessels have a greater risk of embolism formation and reduced hydraulic conductivity under drought. Trees with longer and wider xylem vessels may have a greater hydraulic conductivity and a pitted wall area, more prone to air seeding and embolism under drought conditions. Hence, the larger the vessel size and water conductivity, the higher the risk of embolism; the more protected the xylem transport system is against embolism formation, the less efficient it is in water conductance.

The significant correlations between the trees' past growth metrics and current growth reaction to drought indicate mechanical relationships and guide further research.

\section{Further explanation and exploration of ecological memory effect}

Considering trees longevity and the natural and human disturbances they may face and store in their ecological memory influencing subsequent growth, their past is relevant. Frequently occurring strong thinning may lead to volatile and unstable growing conditions (Cameron 2002; Pretzsch 2020a). Atmospheric deposition of $\mathrm{SO}_{2}$ (Elling et al. 2009; Hauck et al. 2012; Pretzsch 2020b), N (Pretzsch et al. 2014a, b; Etzold et al. 2020), and the impact of the ozone (Matyssek and Sandermann 2003; Löw et al. 2006; Pretzsch and Schütze 2018) may further accelerate or decelerate growth. Finally, abiotic or biotic damage, such as drought (Allen et al. 2010), late frost (Zohner et al. 2020), and biotic events (Kulman 1971; Jactel et al. 2012; Bréda and Badeau 2008), may further impede tree growth. The disturbances combined may cause low- and high-growth years and trigger repeated changes in tree growth and allocation patterns, resulting in highly irregular tree ring and crown patterns. Different growth courses result in specific internal stem structures and crown morphologies. Because of the allometric relationships between stem diameter and crown and root growth, the development of tree dimensions such as tree height, branch length, and branch and root diameter is similar to that of stem growth.

Most modern silvicultural measures, such as wide initial spacing or repeated strong thinning, increase cvar and rng and may contribute to stress predisposition. Measures such as tree species mixing (del Río et al. 2017) and continuously moderate stand density reduction (Pretzsch 2020a) may reduce the inter-annual growth variation and repeated adaption, stabilising tree and stand growth. Natural stands or plantations under self-thinning have regular tree ring widths and crown structures (Dinulică et al. 2015). Reducing irregular growth years slows down juvenile growth or reduces the growth rate oscillation by niche complementarity and asynchronous resource uptake. Higher oscillation of the diameter growth may indicate alternating growing conditions and increased needs for physiological and morphological adaptations that may leave fewer photosynthates for stem growth and reserves. Slow starters with narrow rings first and wide rings later may have future advantages in structure and morphology with longer water transport lengths and advanced tree heights.

The differences in internal stem structure and external crown and root morphology may cause differences in the trees' light interception, hydraulic conduction, or water and nutrient uptake. Further research is required. Hence, the differences in structure cause specific differences in the functioning and growth curve patterns. For instance, degressive courses with the widest rings close to the pith may be triggered by early dominance and may result from advantageous hydraulic conductance in the youth followed by disadvantages growth due to narrower rings lower growth and drought resistance in advanced age (Ryan and Yoder 1997; Hartmann 2011).

This is reflected by functional, structural models (Sievänen et al. 2000, 2008) and patterns of tree rings, crown morphology, or root structure (Pretzsch et al. 2012a, b) may determine water conduction, light interception, and nutrient uptake, respectively. Thus, trees may memorise their past development and are codominant by their internal structures, in addition to their dependency on well-analysed external factors such as size, competition, and site conditions.

\section{Relevance for tree growth analyses, simulation models, and silvicultural prescriptions}

I found that the past can strongly codetermine tree growth and even at the parity of current size, environmental conditions, and competition, trees can significantly differ because of their individual past development. This is highly relevant for tree growth analyses, simulation models, and silvicultural prescriptions.

Ceteris paribus present state conditions, experiments ascribe tree growth responses to the respective experimental factors such as spacing, thinning, or species mixing. However, tree responses at present may be codetermined by the stand development in the longer past. Past tree development may strongly correlate with growth via the trees' internal structure and morphology. For example, the growth 
reactions during thinning may also strongly depend on the trees' past. Even in stands of the same age and stocked by trees with similar tree diameters, the thinning reaction may be much stronger in stands with moderate and slow opening in the youth than in stands with strong crop tree thinning in the past. Avoiding such bias by past development may consider the ecological memory effect by metrics such as cvar, hst, or freq. I suggest their inclusion as covariables in models, alongside the classical predictor variables size, environmental conditions, and competition. That for both species the highest correlation between past and present growth patterns occurred rather simultaneously (Fig. 4) suggests that the memory of past natural or human disturbances may be similar for different tree species.

Dendrometrically based, empirical individual tree simulators commonly predict growth in 1- or 5-year steps over longer time horizons (Pretzsch 2009; Weiskittel et al. 2011; Burkhart and Tomé, 2012). They have generated and stored individual tree trajectories only for the model output. Future models may harness this information to improve the prediction of current and future growth, as demonstrated here by the improved AIC, $\mathrm{R}^{2}$, and RMSE. The modelled structure, crown morphology, and tree ring pattern may be better exploited for the prediction of plant growth, as suggested by Ogle et al. (2015), Fleta-Soriano and Munné-Bosch (2016), and Netzer et al. (2019).

The analysed trees represent forests where the long-term growth course is determined by silvicultural treatment via spacing and thinning. Silvicultural treatment in the further or recent past that is momentous for the growth, resilience, and resistance of trees at present may suggest revision of common silvicultural prescriptions and designs. A tradeoff between repeated growth acceleration triggered by thinning and the future stability and resistance of such trees may question several modern silvicultural prescriptions. The progressive course of growth and low inter-annual growth variation in the long-term and growth deflections in the recent past increased the growth resistance to drought can inform risk-resilient forests. How past silvicultural treatment and other disturbances determine structure and functioning regarding stress resilience could contribute to climatesmart forestry and silviculture (Bowditch et al. 2020). It may facilitate silvicultural prescriptions that consider both wellanalysed options for stress mitigation and stand structures that promote stress reduction (e.g. selecting drought-tolerant species and provenances, reducing stand density, or mixing tree species). This may lead to drought-adapted approaches to individual tree structures and morphologies by shaping a tree's history and ecological memory.

\section{Conclusions}

The strong impact of the tree's past course of growth on drought reactions suggests that antecedent growing conditions and growth determined by silvicultural steering may also codetermine other tree behaviours such as aging, resistance to stress, resilience, recovery, or mortality stronger than assumed so far. An additional $20-30 \%$ of the growth variation between dried-out and control spruce and beeches could be explained by model inclusion of different individual tree history metrics extracted from the tree ring patterns. The trees grew in the same stand and only differed in their individual history; however, their past differed mainly in the growth variation and trend caused by human silvicultural interferences and competitive status. Information regarding the past may raise the variance explanation of growth above $50 \%$ achieved by the classical tree state variables applied so far. The impact of antecedent conditions suggests that silvicultural prescriptions create growth trajectories with beneficial legacy effects. Tree history requires more attention from monitoring, modelling, and silvicultural steering of trees and forest stands.

Supplementary Information The online version contains supplementary material available at https://doi.org/10.1007/s10342-021-01422-8.

Acknowledgements The author would like to acknowledge the networking support of the COST (European Cooperation in Science and Technology) Action CLIMO (Climate-Smart Forestry in Mountain Regions, CA15226), financially supported by the EU Framework Programme for Research and Innovation HORIZON 2020. The publication is also part of the CARE4C project, which has received funding from the European Union's HORIZON 2020 Research and Innovation Programme under the Marie Skłodowska-Curie grant agreement No. 778322. I also thank Bayerische Staatsforsten (BaySF) for supporting the establishment and maintenance of the underlying long-term experiments and to the Bavarian State Ministry for Nutrition, Agriculture, and Forestry for the permanent support of the project W07, entitled "Long-term experimental plots for forest growth and yield research" (\# 7831-22209-2013). I also thank the anonymous reviewers for their constructive criticism.

Author contributions HP initiated and conceptualised the study, evaluated the data, wrote, and revised the manuscript.

Funding Open Access funding enabled and organized by Projekt DEAL.

\section{Declarations}

Conflict of interest The author declares that he has no conflict of interest. 
Open Access This article is licensed under a Creative Commons Attribution 4.0 International License, which permits use, sharing, adaptation, distribution and reproduction in any medium or format, as long as you give appropriate credit to the original author(s) and the source, provide a link to the Creative Commons licence, and indicate if changes were made. The images or other third party material in this article are included in the article's Creative Commons licence, unless indicated otherwise in a credit line to the material. If material is not included in the article's Creative Commons licence and your intended use is not permitted by statutory regulation or exceeds the permitted use, you will need to obtain permission directly from the copyright holder. To view a copy of this licence, visit http://creativecommons.org/licenses/by/4.0/.

\section{References}

Akaike H (1981) Likelihood of a model and information criteria. J Econom 16(1):3-14. https://doi.org/10.1016/0304-4076(81) 90071-3

Aldea J, Bravo F, Bravo-Oviedo A, Ruiz-Peinado R, Rodríguez F, Del Río M (2017) Thinning enhances the species-specific radial increment response to drought in Mediterranean pine-oak stands. Agric for Meteorol 237:371-383. https://doi.org/10.1016/j.agrformet. 2017.02.009

Allen CD, Macalady AK, Chenchouni H, Bachelet D, McDowell N, Vennetier M, Kitzberger T, Rigling A, Breshears D, Hogg E, Fensham R, Zhang Z, Castro J, Demidova N, Lim J-H, Allard G, Running S, Semerci A, Cobb N, Gonzalez P (2010) A global overview of drought and heat-induced tree mortality reveals emerging climate change risks for forests. For Ecol Manag 259(4):660-684. https://doi.org/10.1016/j.foreco.2009.09.001

Assmann E, Franz F (1965) Vorläufige Fichten-Ertragstafel für Bayern. Forstwissenschaftliches Centralblatt 84(1):13-43

Backhaus S, Kreyling J, Grant K, Beierkuhnlein C, Walter J, Jentsch A (2014) Recurrent mild drought events increase resistance toward extreme drought stress. Ecosystems 17(6):1068-1081. https://doi. org/10.1007/s10021-014-9781-5

Barton K (2009) Mu-MIn: Multi-model inference. R Package Version 0.12.2/r18. http://R-Forge.R-project.org/projects/mumin/

Bates D, Mächler M, Bolker B, Walker S (2015) Fitting linear mixedeffects models using lme4. J Stat Softw 67(1):1-48. https://doi. org/10.18637/jss.v067.i01

Bose AK, Moser B, Rigling A, Lehmann MM, Milcu A, Peter M, Rellstab C, Wohlgemuth T, Gessler A (2020) Memory of environmental conditions across generations affects the acclimation potential of scots pine. Plant Cell Environ 43(5):1288-1299. https://doi. org/10.1111/pce.13729

Bowditch E, Santopuoli G, Binder F, del Río M, La Porta N, Kluvankova T, Lesinski J, Motta R, Pach M, Panzazzhi H, Temperli C, Tonon G, Smith M, Velikova V, Weatherall A, Pretzsch H (2020) What is Climate-Smart Forestry? A definition from a multinational collaborative process focused on mountain regions of Europe. Ecosyst Serv 43:101113. https://doi.org/10.1016/j.ecoser. 2020.101113

Bréda N, Badeau V (2008) Forest tree responses to extreme drought and some biotic events: toward selection according to hazard tolerance? CR Geosci 340(9-10):651-662. https://doi.org/10.1016/j. crte.2008.08.003

Burkhart HE, Tomé M (2012) Modelling forest trees and stands. Springer, Berlin

Calama R, Conde M, de Dios-García J, Madrigal G, Vázquez-Piqué J, Gordo FJ, Pardos M (2019) Linking climate, annual growth, and competition in a Mediterranean forest: Pinus pinea in the Spanish northern plateau. Agric for Meteorol 264:309-321. https://doi.org/ 10.3832/ifor3180-013
Camarero JJ, Gazol A, Sangüesa-Barreda G, Cantero A, SánchezSalguero R, Sánchez-Miranda A, Ibáñez R (2018) Forest growth responses to drought at short-and long-term scales in Spain: squeezing the stress memory from tree rings. Front Ecol Evol. https://doi.org/10.3389/fevo.2018.00009

Cameron AD (2002) Importance of early selective thinning in the development of long-term stand stability and improved log quality: a review. Forestry 75(1):25-35. https://doi.org/10.1093/fores try/75.1.25

Coomes DA, Allen RB (2007) Effects of size, competition, and altitude on tree growth. J Ecol 95(5):1084-1097. https://doi.org/10.1111/j. 1365-2745.2007.01280.x

D'Amato AW, Bradford JB, Fraver S, Palik BJ (2013) Effects of thinning on drought vulnerability and climate response in northern temperate forest ecosystems. Ecol Appl 23(8):1735-1742. https:// doi.org/10.1890/13-0677.110.1163/22941932-90001002

de Martonne E (1926) Une Novelle Function Climatologique: L'indice d'aridité. La Météorologie 21:449-458

del Río M, Pretzsch H, Ruíz-Peinado R, Ampoorter E, Annighöfer P, Barbeito I, Bielak K, Brazaitis G, Coll L, Fabrika M, Forrester D, Heym M, Hurt V, Kurylyak V, Lof M, Lombardi F, Madrickiene E, Matovic B, Mohren F (2017) Species interactions increase the temporal stability of community productivity in Pinus sylvestrisFagus sylvatica mixtures across Europe. J Ecol 105(4):10321043. https://doi.org/10.1111/1365-2745.12727

Dinulică F, Albu CT, Borz SA, Vasilescu MM, Petritan IC (2015) Specific structural indices for resonance Norway spruce wood used for violin manufacturing. BioResources 10(4):7525-7543

Elling W, Dittmar C, Pfaffelmoser K, Rötzer T (2009) Dendroecological assessment of the complex causes of decline and recovery of the growth of silver fir (Abies alba Mill.) in Southern Germany. For Ecol Manag 257(4):1175-1187. https://doi.org/10.1016/j. foreco.2008.10.014

Etzold S, Ferretti M, Reinds GJ, Solberg S, Gessler A, Waldner P, Ingerslev M (2020) Nitrogen deposition is the most important environmental driver of the growth of pure, even-aged, and managed European forests. For Ecol Manag 458:117762. https://doi. org/10.1016/j.foreco.2019.117762

Fleta-Soriano E, Munné-Bosch S (2016) Stress memory and the inevitable effects of drought: a physiological perspective. Front Plant Sci 7:143. https://doi.org/10.3389/fpls.2016.00143

Goisser M, Geppert U, Rötzer T, Paya A, Huber A, Kerner R, Matyssek R (2016) Does belowground interaction with Fagus sylvatica increase drought susceptibility to photosynthesis and stem growth in Picea abies? For Ecol Manag 375:268-278. https://doi.org/10. 1016/j.foreco.2016.05.032

Göttlein A, Baumgarten M, Dieler J (2012) Site conditions and treeinternal nutrient partitioning in mature European beech and Norway spruce at the Kranzberger Forst. In: Matyssek R, Schnyder H, Osswald W, Ernst D, Munch JC, Pretzsch H (eds) Growth and defence in plants - resource allocation at multiple scales ecological studies. Springer, Berlin, pp 193-211

Grams TEE, Hesse BD, Gebhardt T, Weikl F, Rötzer T, Kovacs B, Hikino K, Hafner BD, Brunn M, Bauerle T, Häberle KH, Pretzsch H, Pritsch K (2021) The Kroof experiment: realization and efficacy of a recurrent drought experiment plus recovery in a beech/ spruce forest. Ecosphere 12(3):e03399

Häberle KH, Weigt R, Nikolova PS, Reiter IM, Cermak J, Wieser G, Blaschke H, Rötzer T, Pretzsch H, Matyssek R (2012) Case study "Kranzberger Forst": growth and defence in European beech (Fagus sylvatica L.) and Norway Spruce (Picea abies (L.) Karst). In: Matyssek R et al (eds) Growth and defence in plants, ecological studies 220. Springer, Berlin, pp 243-271

Häberle KH, Rötzer T, Pritsch K, Matyssek R (2015) Experimenteller Trockenstress in einem Buchen-Fichten-Mischbestand (KROOF). Mitteilungen der Deutschen Bodenkundlichen Gesellschaft Bd. 
117: 202-206. Jahrestagung München Exkursionsführer 2015, Exkursion-Nr. E-02

Hartmann H (2011) Will a 385 million year-struggle for light has become a struggle for water and carbon? How can trees cope with more frequent climate change-type drought events? Glob Change Biol 17(1):642-655. https://doi.org/10.1111/j.1365-2486. 2010.02248.x

Hauck M, Zimmermann J, Jacob M, Dulamsuren C, Bade C, Ahrends B, Leuschner C (2012) Rapid recovery of stem increment in Norway spruce at reduced SO2 levels in the Harz Mountains, Germany. Environ Pollut 164:132-141. https://doi.org/10.1016/j. envpol.2012.01.026

Hegyi F (1974) A simulation model for managing Jackpine stands. In: Fries J (ed) Growth models for tree and stand simulations. Royal College of Forest, Berlin, p 379

Jactel H, Petit J, Desprez-Loustau ML, Delzon S, Piou D, Battisti A, Koricheva J (2012) Drought effects on damage by forest insects and pathogens: a meta-analysis. Glob Change Biol 18(1):267-276. https://doi.org/10.1111/j.1365-2486.2011.02512.x

Johnstone JF, Allen CD, Franklin JF, Frelich LE, Harvey BJ, Higuera PE, Schoennagel T (2016) Changing disturbance regimes, ecological memory, and forest resilience. Front Ecol Environ 14(7):369378. https://doi.org/10.1002/fee.1311

Kulman HM (1971) Effects of insect defoliation on tree growth and mortality. Annu Rev Entomol 16(1):289-324. https://doi.org/10. 1146/annurev.en.16.010171.001445

Kuznetsova A, Brockhoff PB, Christensen RHB (2017) lmerTest package: tests in linear mixed effects models. J Stat Softw 82(13):1-26. https://doi.org/10.18637/jss.v082.i13

Löw M, Herbinger K, Nunn AJ, Häberle KH, Leuchner M, Heerdt C, Matyssek R (2006) The extraordinary drought of 2003 overrules the ozone impact on adult beech trees (Fagus sylvatica). Trees 20(5):539-548. https://doi.org/10.1007/s00468-006-0069-z

Martín-Benito D, Cherubini P, Del-Río M, Cañellas I (2008) Growth response to climate and drought in Pinus nigra Arn. trees from the different crown classes. Trees 22(3):363-373. https://doi.org/ 10.1007/s00468-007-0191-6

Matyssek R, Sandermann H (2003) Impact of ozone on trees: an ecophysiological perspective. In: Progress in botany. Springer, pp 349-404

Netzer Y, Munitz S, Shtein I, Schwartz A (2019) Structural memory in grapevines: early season water availability affects late-season drought stress severity. Eur J Agron 105:96-103. https://doi.org/ 10.1016/j.eja.2019.02.008

Nickel UT, Weikl F, Kerner R, Schäfer C, Kallenbach C, Munch JC, Pritsch K (2018) Quantitative losses vs. qualitative stability of ectomycorrhizal community responses to 3 years of experimental summer drought in a beechspruce forest. Glob Change Biol 24(2):e560-e576. https://doi.org/10.1111/gcb.13957

Nikolova PS, Zang C, Pretzsch H (2011) Combining tree-ring analyses on stems and coarse roots to study the growth dynamics of forest trees: a case study on Norway spruce (Picea abies [L.] H. Karst). Trees 25(5):859-872. https://doi.org/10.1007/s00468-011-0561-y

Ogle K, Barber JJ, Barron-Gafford GA, Bentley LP, Young JM, Huxman TE, Loik ME, Tissue DT (2015) Quantifying ecological memory in plant and ecosystem processes. Ecol Lett 18(3):221235. https://doi.org/10.1111/ele.12399

Peltier DM, Ogle K (2019) Legacies of more frequent droughts in ponderosa pine across the western United States. Glob Change Biol 25(11):3803-3816. https://doi.org/10.1111/gcb.14720

Pinheiro J, Bates D, DebRoy S, Sarkar D, R Core Team (2018) nlme: Linear and nonlinear mixed-effects models. $\mathrm{R}$ package version 3.1-137." R Found. Stat. Comput. https://CRAN.R-project.org/ package $=$ nlme. Accessed 19 July 2018

Pretzsch H (2009) Forest dynamics, growth, and yield. Springer, Heidelberg, p 664
Pretzsch H (2020a) Density and growth of forest stands revisited. Effect of temporal scale of observation, site quality, and thinning. For Ecol Manag 460:117879

Pretzsch H (2020b) The course of tree growth. Theory and reality, Arthur Tamm review. For Ecol Manag 478:118508. https://doi. org/10.1016/j.foreco.2020.118508

Pretzsch H (2021a) Trees grow modulated by the ecological memory of their past growth. Consequences for Monitoring, Modelling, and Silvicultural Treatment. For Ecol Manag 487:118982. https://doi. org/10.1016/j.foreco.2021.118982

Pretzsch H (2021b) The social drift of trees. Consequence for growth trend detection, stand dynamics, and silviculture. Eur J for Res 140(3):703-719

Pretzsch H, Schütze G (2018) Growth recovery of mature Norway spruce and European beech from chronic O 3 stress. Eur J Forest Res 137(2):251-263. https://doi.org/10.1007/s10342-018-1106-3

Pretzsch H, Kahn M, Grote R (1998a) Die Fichten-Buchen-Mischbestände des Sonderforschungsbereiches' Wachstum oder Parasitenabwehr? « im Kranzberger Forst. Forstwissenschaftliches Centralblatt 117(1):241-257

Pretzsch H, Kahn M, Grote R (1998b) Die Fichten-Buchen-Mischbestände des Sonderforschungsbereiches „Wachstum oder Parasitenabwehr?"im Kranzberger Forst. Forstwissenschaftliches Centralblatt Vereinigt Mit Tharandter Forstliches Jahrbuch 117(1-6):241-257

Pretzsch H, Uhl E, Biber P, Schütze G, Coates KD (2012a) Changes in allometry between coarse roots and shoots of Lodgepole pine (Pinus contorta DOUGL. Ex. LOUD) along a stress gradient in the sub-boreal forest zone of British Columbia. Scand J for Res 27(6):532-544

Pretzsch H, Uhl E, Biber P, Schütze G, Coates D (2012b) Change of allometry between coarse root and shoot of Lodgepole pine (Pinus contorta DOUGL. Ex. LOUD.) along a stress gradient in the sub-boreal forest zone of British Columbia. Scand J for Res 27(6):532-544. https://doi.org/10.1080/02827581.2012.672583

Pretzsch H, Schütze G, Uhl E (2013a) Resistance of European tree species to drought stress in mixed versus pure forests: evidence of stress release by interspecific facilitation. Plant Biol 15:483-495

Pretzsch H, Schütze G, Uhl E (2013b) Resistance of European tree species to drought stress in mixed versus pure forests: evidence of stress release by inter-specific facilitation. Plant Biol 15(3):483495. https://doi.org/10.1111/j.1438-8677.2012.00670.x

Pretzsch H, Biber P, Schütze G, Uhl E, Rötzer T (2014a) Forest stand growth dynamics in Central Europe have accelerated since 1870. Nat Commun 5(1):1-10. https://doi.org/10.1038/ncomms5967

Pretzsch H, Rötzer T, Matyssek R, Grams TEE, Häberle KH, Pritsch K, Munch JC (2014b) Mixed Norway spruce (Picea abies [L.] Karst) and European beech (Fagus sylvatica [L.]) stand under drought, from reaction pattern to mechanism. Trees 28(5):1305-1321. https://doi.org/10.1007/s00468-014-1035-9

Pretzsch H, Bauerle T, Häberle KH, Matyssek R, Schütze G, Rötzer $\mathrm{T}$ (2016) Tree diameter growth after root trenching in a mature mixed stand of Norway spruce (Picea abies (L.) Karst) and European beech (Fagus sylvatica [L.]). Trees 30(5):1761-1773

Pretzsch H, Grams T, Häberle KH, Pritsch K, Bauerle T, Rötzer T (2020) Growth and mortality of Norway spruce and European beech in monospecific and mixed-species stands under natural episodic and experimentally extended droughts. Results of KROOF throughfall exclusion experiment. Trees. https://doi.org/10.1007/ s00468-020-01973-0

Prodan M (1968a) Einzelbaum, Stichprobe, and Versuchsfläche. Allg Forst-Und Jagdzeitung 139(10):239-248

Prodan M (1968b) Zur Gesetzmäßigkeit der Flächenverteilung von Bäumen. Allgemeine Forst- und Jagdzeitung 214-217

Quan C, Han S, Utescher T, Zhang C, Liu YS (2013) Validation of temperature-precipitation based aridity index: paleoclimatic 
implications. Palaeogeogr Palaeoclimatol Palaeoecol 386:86-95. https://doi.org/10.1016/j.palaeo.2013.05.008

R Core Team (2017) R: A language and environment for statistical computing. R Foundation for Statistical Computing, Vienna . https://doi.org/10.1093/jxb/10.2.290

Rico L, Ogaya R, Barbeta A, Penuelas J (2014) Changes in the DNA methylation fingerprint of $\mathrm{Q}$. uercus ilex trees in response to experimental field drought simulating projected climate change. Plant Biol 16(2):419-427. https://doi.org/10.1111/plb.12049

Rötzer T, Seifert T, Gayler S, Priesack E, Pretzsch H (2012) Effects of stress and defense allocation on tree growth: simulation results at the individual and stand level. In: Matyssek R et al (eds) Growth and defense in plants: resource allocation at multiple scales. Springer, Berlin, pp 401-432

Rötzer T, Biber P, Moser A, Schäfer C, Pretzsch H (2017a) Stem and root diameter growth of European beech and Norway spruce under extreme drought conditions. For Ecol Manage 406:184-195. https://doi.org/10.1016/j.foreco.2017.09.070

Rötzer T, Häberle KH, Kallenbach C, Matyssek R, Schüunk G, Pretzsch $\mathrm{H}$ (2017b) Tree species and size drive the water consumption of beech/spruce forests-a simulation study highlighting growth under water limitation. Plant Soil 418(1-2):337-356. https://doi.org/10. 1007/s11104-017-3306-x

Ryan MG, Yoder BJ (1997) Hydraulic limits tree height and tree growth. Bioscience 47(4):235-242

Schäfer C, Rötzer T, Thurm EA, Biber P, Kallenbach C, Pretzsch H (2019) Growth and tree water deficit of mixed Norway spruce and European beech at different heights in a tree and under heavy drought. Forests 10(7):577. https://doi.org/10.3390/f10070577

Schober R (1975) Ertragstafeln wichtiger Baumarten. JD Sauerländer's Verlag, Berlin

Sievänen R, Nikinmaa E, Nygren P, Ozier-Lafontaine H, Perttunen J, Hakula $\mathrm{H}$ (2000) Components of functional structural tree models. Ann for Sci 57(5):399-412. https://doi.org/10.1051/forest:20001 31

Sievänen R, Perttunen J, Nikinmaa E, Kaitaniemi P (2008) Toward extension of a single tree functional-structural model of Scots pine to stand level: effect of the canopy of randomly distributed, identical trees on development of tree structure. Funct Plant Biol 35:964-975. https://doi.org/10.1071/FP08077

Sohn JA, Saha S, Bauhus J (2016) Potential of forest thinning to mitigate drought stress: a meta-analysis. For Ecol Manag 380:261273. https://doi.org/10.1016/j.foreco.2016.07.046

Steckel M, Moser WK, del Río M, Pretzsch H (2020) Implications of reduced stand density on tree growth and drought susceptibility: a study of three species under varying climate conditions. Forests 11(6):627

Tesche M (1992) Immediate and long-term (memory) responses of Picea abies to a single growing season of SO2-exposure or moderate drought. For Ecol Manag 51(1-3):179-186. https://doi.org/ 10.1016/0378-1127(92)90483-P

von Bertalanffy L (1951) Theoretische biologie: II. Band, Stoffwechsel, Wachstum, 2nd edn. A Francke AG, p 418

Walter J, Nagy L, Hein R, Rascher U, Beierkuhnlein C, Willner E, Jentsch A (2011) Do plants remember drought? Hints towards drought memory in grasses. Environ Exp Bot 71(1):34-40. https:// doi.org/10.1016/j.envexpbot.2010.10.020

Webster CR, Lorimer CG (2003) Comparative growing space efficiency of four tree species in mixed conifer-hardwood forests. For Ecol Manag 177(1-3):361-377. https://doi.org/10.1016/ S0378-1127(02)00394-8

Weiskittel AR, Hann DW, Kershaw JA, Vanclay JK (2011) Forest growth and yield modelling. Wiley, Hoboken

Zohner CM, Mo L, Renner SS, Svenning JC, Vitasse Y, Benito BM, Reich PB (2020) The late-spring frost risk between 1959 and 2017 decreased in North America but increased in Europe and Asia. Proc Natl Acad Sci 117(22):12192-12200. https://doi.org/10. 1073/pnas.1920816117

Zweifel R, Sterck F (2018) Conceptual tree model explaining legacy effects on stem growth. Front for Glob Changes 1:9. https://doi. org/10.3389/ffgc.2018.00009

Publisher's Note Springer Nature remains neutral with regard to jurisdictional claims in published maps and institutional affiliations. 